\title{
Applications of Soil Pollution and Statistical Models on the Assessment and Distributions of the Heavy Metals on the Typical Paint Manufacturing Waste Contaminated Soil of Niger Delta Nigeria
}

\author{
Uzoije $^{1 *}$, Atulegwu Patrick ${ }^{1}$ and Nwigwe Chrysogonus ${ }^{2}$ \\ ${ }^{1}$ Department of Environmental Technology, Federal University of Technology Owerri Nigeria \\ ${ }^{2}$ Department of Statistics, Federal University of Technology Owerri Nigeria
}

Submission: July 14, 2018; Published: August 14, 2018

*Corresponding author: Uzoije, Atulegwu Patrick, Department of Environmental Technology, Federal University of Technology Owerri, Nigeria, email: atulegwuuzoije@yahoo.com

\begin{abstract}
Unguarded waste disposal with its concomitant environmental degradation has being a global concern in recent times. Cases of waste disposal from paint manufacturing outfits were not left out in his issue. Study on the assessment of the contaminated soil by waste from paint manufacturing activities has been carried out in a typical Niger delta soil. The study area was divided into four sampling sections, wherein five samples were randomly taken from each segment, making a total of twenty soil samples. The sampling sites were designated as SS2, SS3, SS4, and SS5 which represented; the main discharge point, former discharge point which was abandoned five years ago, main gate and spill points respectively the control site was also located, and five soil samples were randomly collected therein. Each sample was analyzed for $\mathrm{Pb}, \mathrm{Zn}, \mathrm{Cu}$, $\mathrm{Cr}, \mathrm{Ni}, \mathrm{Cd}, \mathrm{Mn}$ and As using standard methods. The average Heavy metal concentration values in the study sites were apparently higher than the control site. However, the sampling sites were impacted at varying levels as follows $\mathrm{SS} 2>\mathrm{SS} 4>\mathrm{SS} 5>\mathrm{SS} 3$. The level of impact of $\mathrm{Cu}, \mathrm{As}, \mathrm{Cr}, \mathrm{Ni}, \mathrm{Pb}$ and $\mathrm{Mn}$ in the entire study area was quantified in percentage and presented in descending order as $82,62,52,39,24$ and $12 \%$ respectively. Elevation of the study sites and Spatial Distribution of the metals were studied with the aid of GPS and the data produced with ARC GIS. The Distribution of the metals were largely affected by the elevation of various sampling sites. Most metals were leached to lower elevations despite the proximity of the sites to the source of discharge. There was low Pollution index (PI) of between 0.01-0.068 for $\mathrm{Cu}$ and $\mathrm{Zn}$ in all the study sites whereas high PI of between 21.5-12.5 was recorded for Mn in SS3, SS4 and SS5. From the index standards, the soil was contaminated, on the average with Cr, Cu, $\mathrm{Zn}, \mathrm{As}, \mathrm{Ni}$ and $\mathrm{Pb}$ at low level and moderately contaminated with $\mathrm{Mn}$ and $\mathrm{Cd}$. On the bivariate analysis, there was strong correlation between $\mathrm{Cu}$ and $\mathrm{Pb}, \mathrm{Zn}$ with $\mathrm{As}$ and $\mathrm{Cr}$, Ni with $\mathrm{Cr}$ and As. In the principal component analysis (PAC), As and $\mathrm{Cu}$ have the highest variation values of $0.979 \mathrm{for}$ As and $0.987 \mathrm{Cu}$ in components 1 and 2 respectively and these two components control $91.004 \%$ of the total variation. By the analysis of variance, there was no significant difference between heavy metals in the sampling sites, however, the Post-Hoc analysis confirmed significant difference in the metal discharge between (SS1), and SS2, SS3 SS4 and SS5 respectively, affirming that the discharge from the paint manufacturing outfits essentially contributed to the prevailing heavy metal concentrations in the sites.
\end{abstract}

Keywords: Pollution Index Model; Heavy Metals; Paint Cottage Industry; Waste; Distribution; Soil

\section{Introduction}

Researchers in the last few decades have established that poorly disposed industrial waste, agricultural activities through applications of pesticides and herbicides; smelting activities, mining and vehicular emissions as sources of heavy metal pollution [1]. Although, soil acts as repository to many heavy metals, in so doing preventing the metals from getting to surface and ground water, however, heavy metals from the anthropogenic sources mentioned pollute the top soil, especially the loose soil, and eventually infiltrate through the soil matrix to the aquifer depending on their affinity to the soil $[2,3]$. Some are washed by surface runoff to pollute the surface water and sediments [4-7]. Scientific research has also proved that most heavy metals inhibit the growth, photosynthesis, stomata function and damage the roots of plants [8-10]. In the soil, heavy metals exhibit inhibitory effects on microbial activity and outright death of most macro organisms, resulting to poor soil quality $[11,12]$ Following the policy on economic revamp and recovery, Nigerian government advised and empowered people to establish small scale enterprises particularly on production of goods and artisanship training. This policy triggered aggressive industrialization at small scale and job creation for the teeming 
populace. With industrialization and consequent urbanization, quality of the eco-system was compromised [13] leading to pollution of environment. It is not new a report that Pollution effects from the aforementioned activities take a significant toll on all aspects of the environmental media. In recent times however, efforts by the industrialists have been geared towards stemming the tide due to the renewed concern by the government and other stake holders about the quality of the environment. In south eastern Nigeria where appreciable cottage industrial activities have been recorded, no comprehensive research has been carried out around those industrial clusters to determine the extent of environmental impact occasioned by their activities. It has been observed that the pollution impacts on the environment have long term effects. Some discharges from these clusters over time, form complexes with the immediate environment to produce other more dangerous forms which results to more environmental perturbation [14]. This study therefore provides an information on the degree of soil pollution from such industrial clusters. Moreover, the work will serve as a platform on which the environmental monitoring agents and other stakeholders base their reports on and in that light, make necessary recommendations on the treatment or remediation approaches acceptable in the international best practices. The study location is a cluster of semi and medium scale enterprises of paint production. Paint production has been going on in the study site for decades without proper waste disposal and treatment facility in place. Waste from various paint manufacturing units are being discharged on land for decades without recourse to its environmental implications. Residues of the active ingredients in the paint waste which include and not limited to metallic and non-metallic radicals, heavy metals and organic substances [15-17] cause varying degrees of soil pollution [9]. several researches have also cited literatures describing the recalcitrant and non-recalcitrant properties of these paint-waste and associated substances, most prominent is the recalcitrant tendency of the heavy metals in soil medium [18,19], translocation and accumulation of metals in the tissues of plant and animals, vulnerability of the substances to ground and surface water pollution $[16,13]$. The substances tend to degrade the soil quality by rendering inactive and reducing the availability of soil microorganisms [4] with its attendant poor crop yield and starvation. Thus, this study aims at assessing the level of heavy metal pollution in the soil of the paint manufacturing cottage industrial cluster and also to get the exact values of the pollutant using pollution index models.

\section{Materials and Methods}

The study area is located in Aba, the commercial nerve center of eastern Nigeria where many cottage industries are located. The location stands on geological setting typical of Niger Delta region. The study area was divided into four segments designated with the following codes SS2, SS3, SS4, and SS5. The codes represent the main discharge point, former discharge point which was abandoned five years ago, main gate and spill points respectively. Main gate and spill points are spots where the paint cans which are not filled to the required level are filled). Control sampling point which was located in a farm land $5 \mathrm{~km}$ from the study area was designated as SS1. A total of 20 Soil samples were collected randomly at the range of $0-1.5 \mathrm{~m}$ depth from each segment making a ground total of 80 samples from the entire study area. The collected soil samples were dried at room temperature, sieved to remove debris, sand and gravel before grinding them into powder with a ball grinder. Digestion and extraction of heavy metals under investigation were carried out according to EPA method 3052 (USEPA 1996). The extracts were analyze to measure $\mathrm{Pb}, \mathrm{Zn}, \mathrm{Cu}, \mathrm{Cr}, \mathrm{Ni}, \mathrm{Cd}, \mathrm{Mn}$ and As using 7700X Inductively Coupled Plasma-Mass Spectrometer (Agilent, USA) and full. Description of the analytical methods can be found [1].

\section{Data Analysis}

Pollution models were adopted to evaluate the extent of metal pollution of the study area. Use of Pollution index (PI), pollution load index (PLI), Degree of contamination (DC), Geoaccumulation index (GAI) and potential ecological risk index (RI) were made for the data analysis. Basic Statistical tools were also used to determine the level of correlation among the metals and the sampling sites. The data were also subjected to multivariate analysis in which principal component analysis (PCA) was applied to determine the similarity of distribution among the heavy metals. Analysis of Variance (ANOVA) was used to investigate if there is significant difference in the mean deposits of the metals in the sites. The Least-Square significant difference was then used to mean deposits of the metals between any two pair of sites. Statistical analyses such as ANOVA, correlation, principal component analysis and PostHoc analysis were carried out with the aid of Statistical Package for Social Sciences (SPSS 20.0) The information gotten from taking the co-ordinates of different sampling points was used with the aid of GIS to determine the spatial distribution of the disposed paint effluents on the surrounding soil Pollution index and pollution load of the heavy metals were evaluated using the following models.

$$
P_{L}=\frac{c_{i}}{s_{i}}
$$

$\mathrm{P}_{\mathrm{L}}=$ pollution index for a given metal

$\mathrm{C}_{\mathrm{i}}=$ concentration of a given metal in the soil.

$\mathrm{S}_{\mathrm{i}}=$ standards for soil environmental quality, which is based on standards for soil quality as specified by the Federal Ministry of Environment (FMEnv) Nigeria.

The load pollution index (PLI) is expressed as follows:

$$
P L I=\left(P I_{1} * P I_{2} * P I_{3} * P I_{4} * \ldots \ldots \ldots . . . P I_{n}\right)^{1 / n}
$$

Where $P I_{1} * P I_{2} * P I_{3} * P I_{4} * \ldots \ldots \ldots . . . P I_{n} \mid$

pollution indices for various metals, and $\mathrm{n}$ is the number of metals under study. The Degree of contamination $\left(D_{C}\right)$ of various metals is calculated as follows; 


$$
D_{c}=\sum_{1}^{n} F_{I}
$$

Where $\mathrm{F}_{\mathrm{I}}$ is the contamination factor expressed as

$$
\mathrm{F}_{\mathrm{i}}=\mathrm{C}_{\mathrm{i}} / \mathrm{S}_{\mathrm{i}}-1
$$

\section{$\mathrm{n}=$ Normative value}

The data obtained was also subjected to Geo-accumulation index (GAI) . This further assess the level of contamination by comparing the measured and the background values which is expressed as

$$
\mathrm{GAI}=\log _{2}\left[\mathrm{C}_{\mathrm{n}} /\left(1.5 \mathrm{~B}_{\mathrm{n}}\right)\right]
$$

$\mathrm{C}_{\mathrm{n}}$ is concentration of $\mathrm{nth}$ metals. $\mathrm{Bn}$ is geochemical Background values i.e content of the examined elements in the reference location
Further study was carried out to assess the potential ecological risk which is expressed as the summation of the risk factors of the heavy metals under study. Equation 6 represents the potential ecological risk

$$
P E R I=\sum E_{I}
$$

$$
\text { Where } E_{I}=T_{I} f_{I}=T_{I} \frac{C_{I}}{B I} \text { । }
$$

$\mathrm{E}_{\mathrm{I}}$ Represents the potential ecological risk index for individual heavy metals or single potential ecological risk index whereas PERI or comprehensive potential ecological risk, is the summation of the single potential ecological risk. T_I is toxic respond factor. T_I for various metal is given as $\mathrm{Hg}=40, \mathrm{Cd}=30$, $\mathrm{As}=10, \mathrm{Ni}=5, \mathrm{Cu}=5, \mathrm{~Pb}=5 \mathrm{Cr}=2, \mathrm{Zn}=1$. The information on the heavy metal concentrations of the control site represents the background concentration in the unpolluted site $\mathrm{B}_{\mathrm{I}}$.

\section{Results and Discussions}

\section{Average Heavy Metal Concentration}

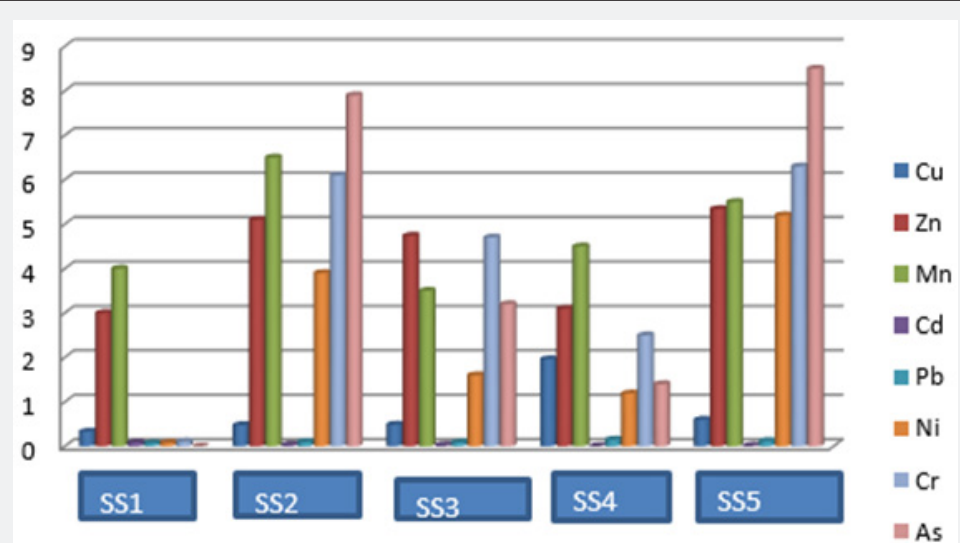

Figure 1: average concentrations of the heavy metals in various sites.

The column plots shown in Figure 1 summarize the average concentration values of the metals investigated in each of the sampling sites designated as SS1, SS2, SS3, SS4 and SS5. The Heavy metal values in SS1 are considerably lower than that of the effluent receiving sites. Being the control site where no discharge took place, the prevailing low concentrations of all the metals are expected. The apparent difference in concentration values of the heavy metals in the control site (SS1) from the effluent receiving sites implies that the investigated metals impacted on the soils of the receiving sites which received the paint manufacturing effluents. Within the receiving sites, however, variations were observed on the heavy metal concentration values. Heavy metal contents in SS2, SS4 and SS5 showed higher values than those in SS3. The scenario is expected because the site 3(SS3) has not been used as discharge point. Low heavy metal concentrations observed on site 3 , could be attributed to the effects of natural attenuation of the metals by the soil. Having been out of use as a discharge point for a considerable long time, the low heavy metal values in SS3 shows how responsive the soil in the site is to natural attenuation of metals. Nevertheless, heavy metal contents in the sample sites (SS4) and SS5 are comparably high, perhaps both sites receive some levels of impact having being used as top-up points. When compared with the level of heavy metals in various sampling sites, soil samples of SS2 have the highest concentration level. Based on the environmental standards for soil quality in Nigeria [20], virtually all the sites were impacted by $\mathrm{Cu}, \mathrm{Mn}, \mathrm{Ni}, \mathrm{Cd}$, As and $\mathrm{Cr}$ except $\mathrm{Zn}$. The level of impact was quantified in percentage and arranged in decrease order of $82,62,52,39,24$ and $12 \%$ for $\mathrm{Cu}, \mathrm{As}, \mathrm{Cr}, \mathrm{Ni}, \mathrm{Pb}$ and $\mathrm{Mn}$ respectively.

\section{Elevation and Spatial Distribution of Heavy Metals}

Elevation of the sampling sites were determined and their co-ordinates measured and the results were presented in one dimensional contour plot with colours to distinguish various sampling sites. Also, three dimensional view of the entire elevation result differentiating the sample site with colours was presented. The elevation plots shown in Figure 2 revealed that the elevation decreased in the following order SS2> SS1> SS3 $>$ SS4 $>$ SS5. Spatial distribution patterns of the heavy metals in all the sampling points were represented in one and three dimensional distribution plot shown in Figures 3-7 representing 
$\mathrm{Cu}, \mathrm{Zn}, \mathrm{Cd}, \mathrm{Pb}$ and $\mathrm{Mn}$. Plots for $\mathrm{Ni}, \mathrm{Cr}$ and as are not shown for brevity. Colours and contour points in the plots were used to interpret the pattern of distributions in the sites. Red and purple colours depict dense and sparse distributions respectively. In Figure 3, Distribution of $\mathrm{Cu}$ recorded the highest concentration value inSS4 at contour points presenting dense distribution value of between $0.6-0.62 \mathrm{mg} / \mathrm{kg}$ and the lowest values at contour points showing sparse distribution value range of 0.28-0.34 in SS2. The apparent $\mathrm{Cu}$ distribution variance as shown in the fig. might have been due to difference in elevation. Being the main discharge point, it is expected that the concentration values of all the metals under investigation would have been high at SS2 but due to high elevation it is possible that metals like $\mathrm{Cu}$ is likely to leached to the lower elevation [17] due to low affinity to the soil matrix, giving rise to the seeming high $\mathrm{Cu}$ concentration value at SS4. Natural occurrence could have also contributed to such glaring increase in SS4 as reported by [11] Figure 4 shows the distribution of $\mathrm{Zn}$ in various sampling locations. Distribution in soil sampling SS3 was observed to have the highest value with contour points depicting dense distribution value of between 0.7 $0.74 \mathrm{mg} / \mathrm{kg}$ while the lowest distribution was observed in SS1, SS2, and SS4 with contour points showing sparse distribution value within the range of between -0.05 to $0 \mathrm{mg} / / \mathrm{kg}$. The site (SS3) is the former discharge area which has not received the paint effluent for a considerable long time ought to record low metal concentration value due to natural attenuation, but the prevailing high $\mathrm{Zn}$ distribution pattern could be a case of natural Zn deposit in SS3. It is also possible that Zn substance which is a component of the former discharge might have remained recalcitrant in soil of SS3 site [21]. Distribution of manganese was dense in SS2 with contour point showing values between 6.3 and $6.5 \mathrm{mg} / \mathrm{kg}$ and sparsely distributed at SS3 with contour points showcasing Mn values of between 3.5 and $3.9 \mathrm{mg} / \mathrm{kg}$ as depicted in Figure 5. The skewed manganese distribution to SS2 is expected because the site is the main discharge point where the major effluents from the paint manufacturing cluster is discharged. In essence, the high Mn value observed in SS2 could be attributed to high bioavailability occasioned by effluent discharge. Change of elevation did not make much impact on Mn distribution probably due to apparent slight difference in elevation. Most importantly, it is possible that the soils of SS2 have higher sorption capacity for manganese ions [22] than SS4 and SS5 which receive similar impact. Also, the seeming high manganese distribution could be attributed to effects of soil properties such $\mathrm{Ph}$, organic matter, ion-exchange [23] Distribution of Cd was observed to have recorded the highest value in the control site, SS1with contour points indicating $\mathrm{Cd}$ values between $0.09-0.095 \mathrm{mg} / \mathrm{kg}$ and lowest value at SS4 with contour points $0-0.005 \mathrm{mg} / \mathrm{kg}$. High Cd value recorded in the control site could be as a result of natural occurrence and as well suggested that the paint effluent contains low $\mathrm{Cd}$ value. It is also possibly that $\mathrm{Cd}$ essentially underwent certain reactions with other effluent ingredients in the sampling sites, leading to its sequestration [24]. In SS2 and SS5, Pb distributions recorded the lowest values of -0.01 and $0 \mathrm{mg} / \mathrm{kg}$ with highest values of between 0.13 and $0.15 \mathrm{mg} / \mathrm{kg}$ in SS4 while the same contour value 0.05 and $0.08 \mathrm{mg} / \mathrm{kg}$, in between the extreme values were observed in SS1 and SS3. Distributions of $\mathrm{Ni}, \mathrm{Cr}$ and as were prominent in all the paint effluent receiving sites (SS2, SS3, SS4 and SS5) but quite negligible in the control site, suggesting the paint effluent had impacted on the sites with the heavy metals. Although their contour diagrams are not shown for brevity, the distributions were dense in the sites SS2, SS3, SS4 and SS5) with average contour values of $\mathrm{Ni}, \mathrm{Cr}$ and as at $1.2,2.1$ and $3.5 \mathrm{mg} / \mathrm{kg}$ respectively.

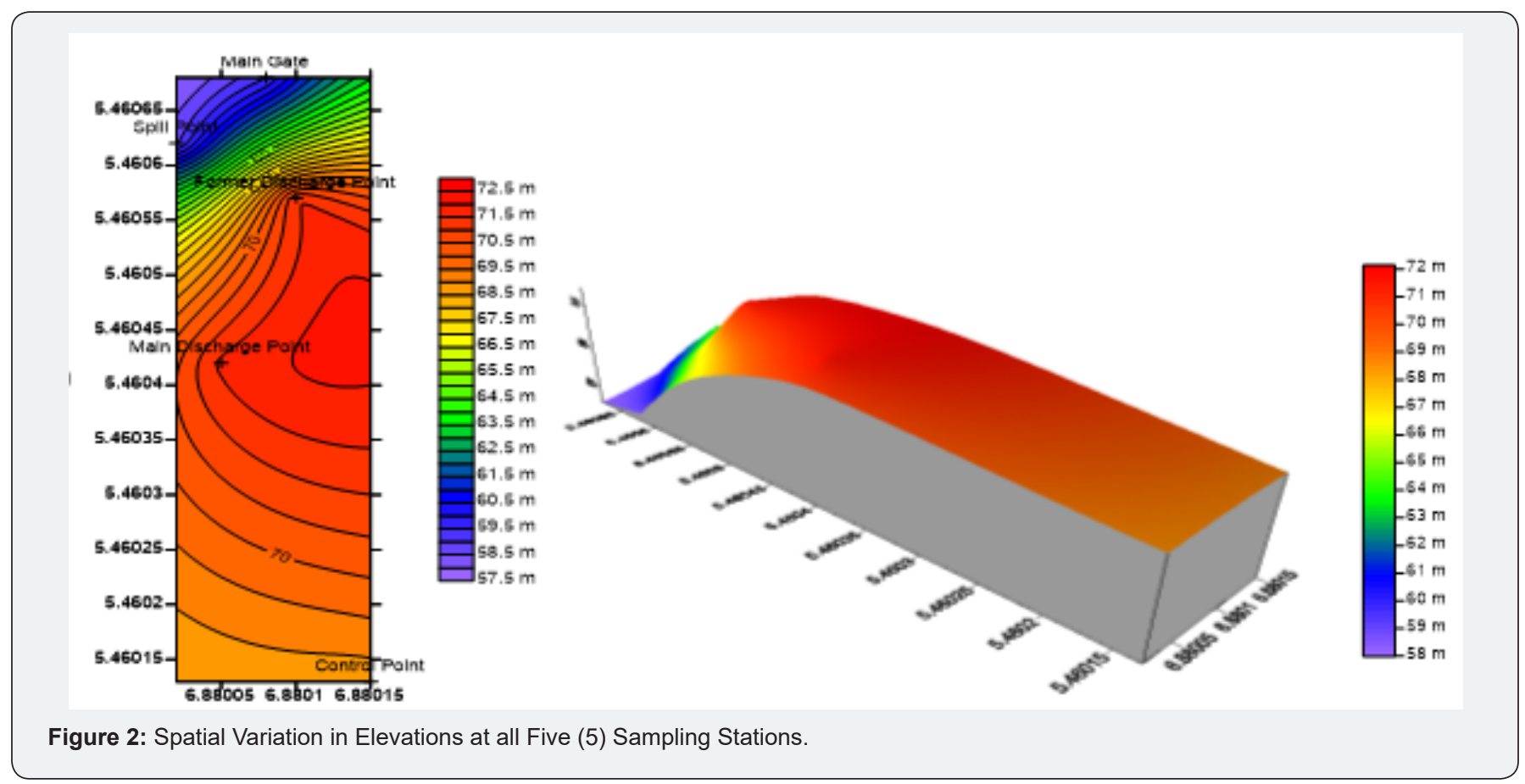




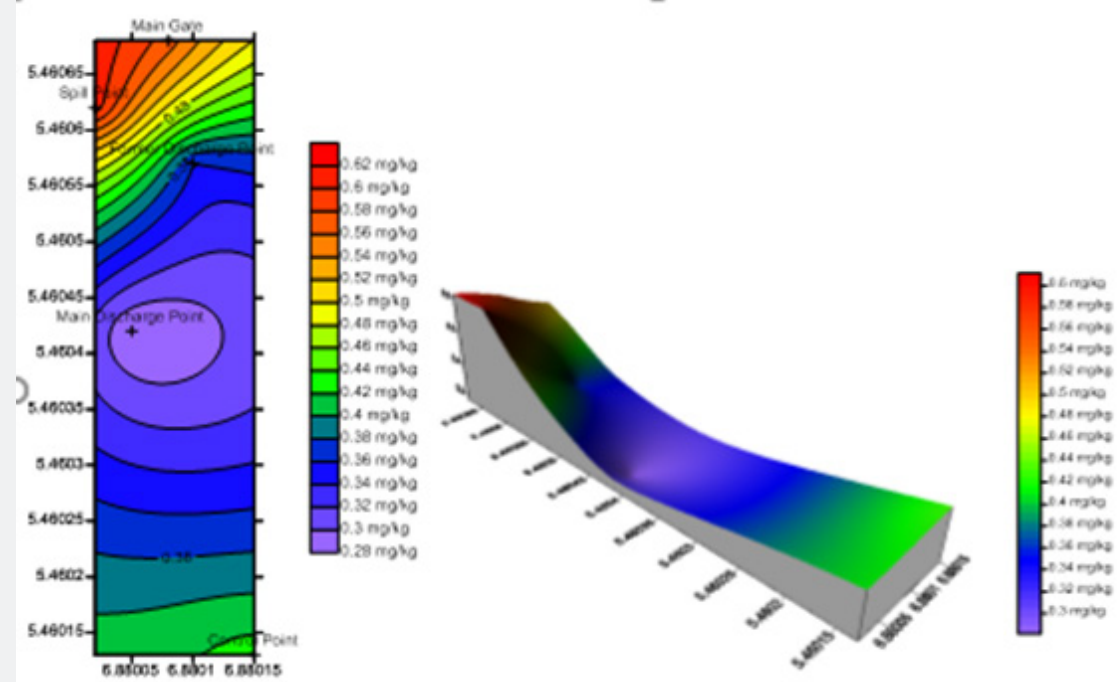

Figure 3: Spatial Distribution of $\mathrm{Cu}$ in soil of the study Area.
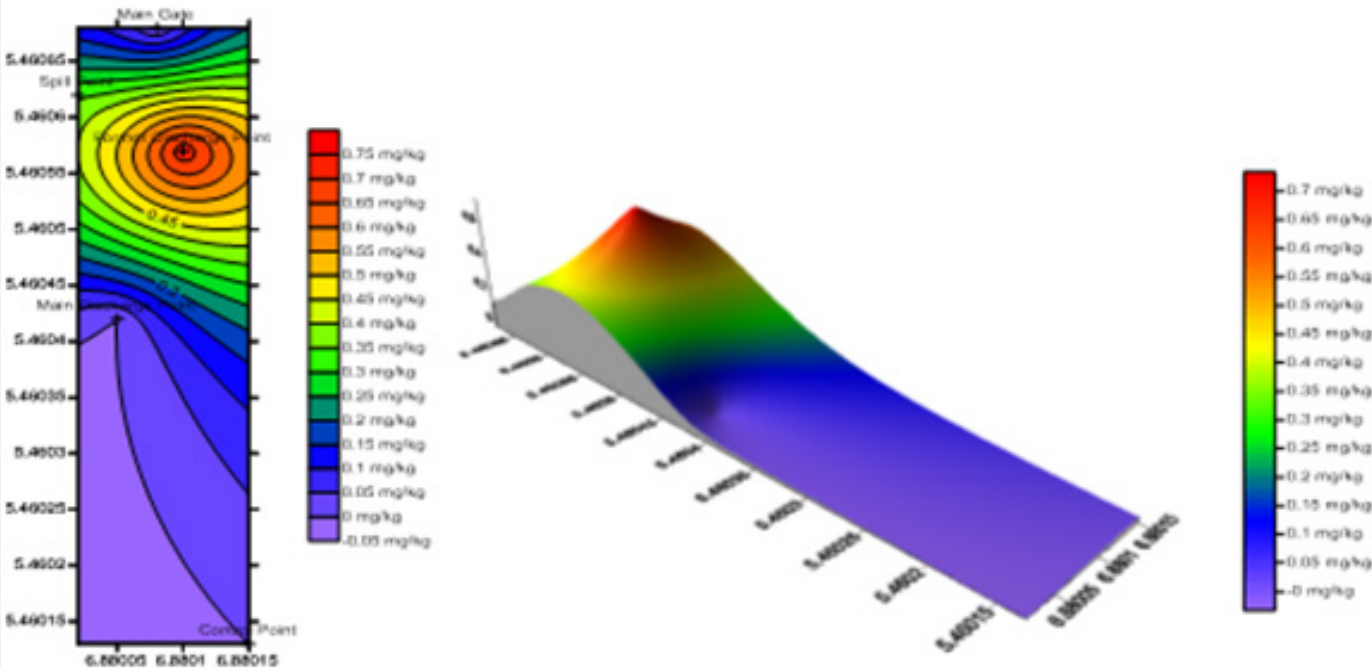

Figure 4: Spatial Distribution of $\mathrm{Zn}$ in Soil of the Study Area.
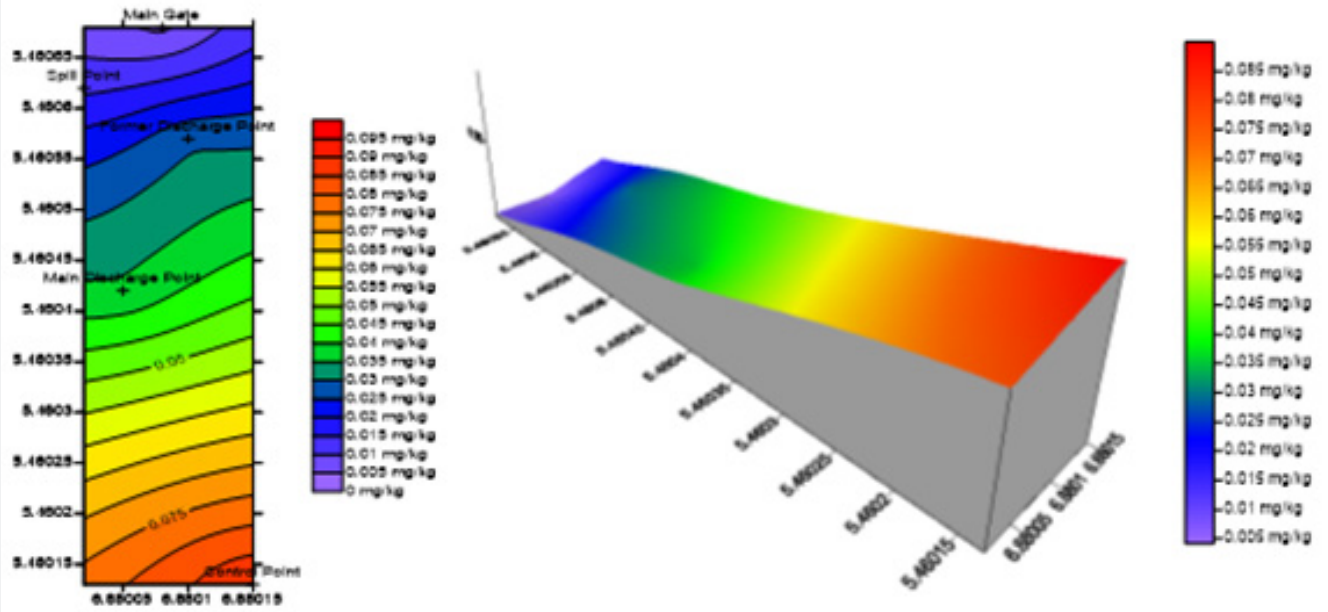

Figure 5: Spatial Distribution of $\mathrm{Mn}$ in Soil of the Study Area. 


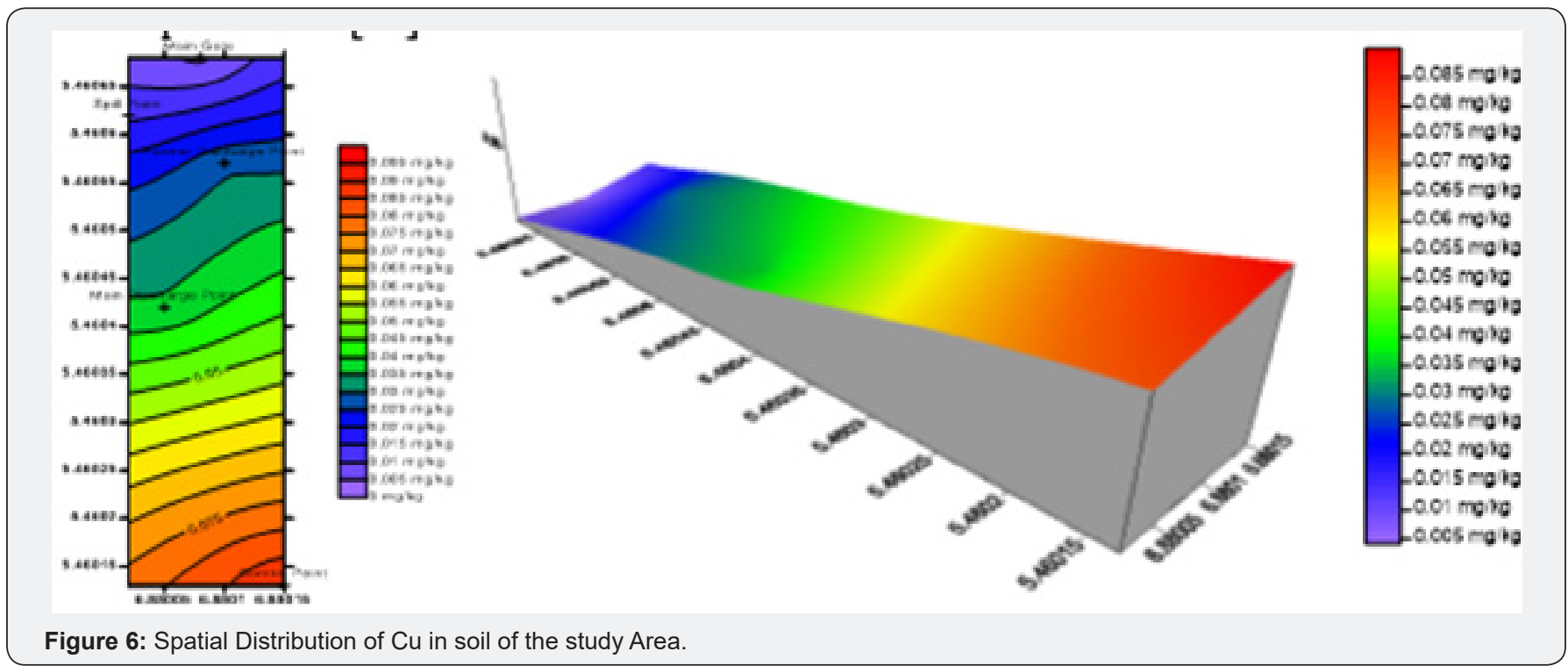

Figure 6: Spatial Distribution of Cu in soil of the study Area

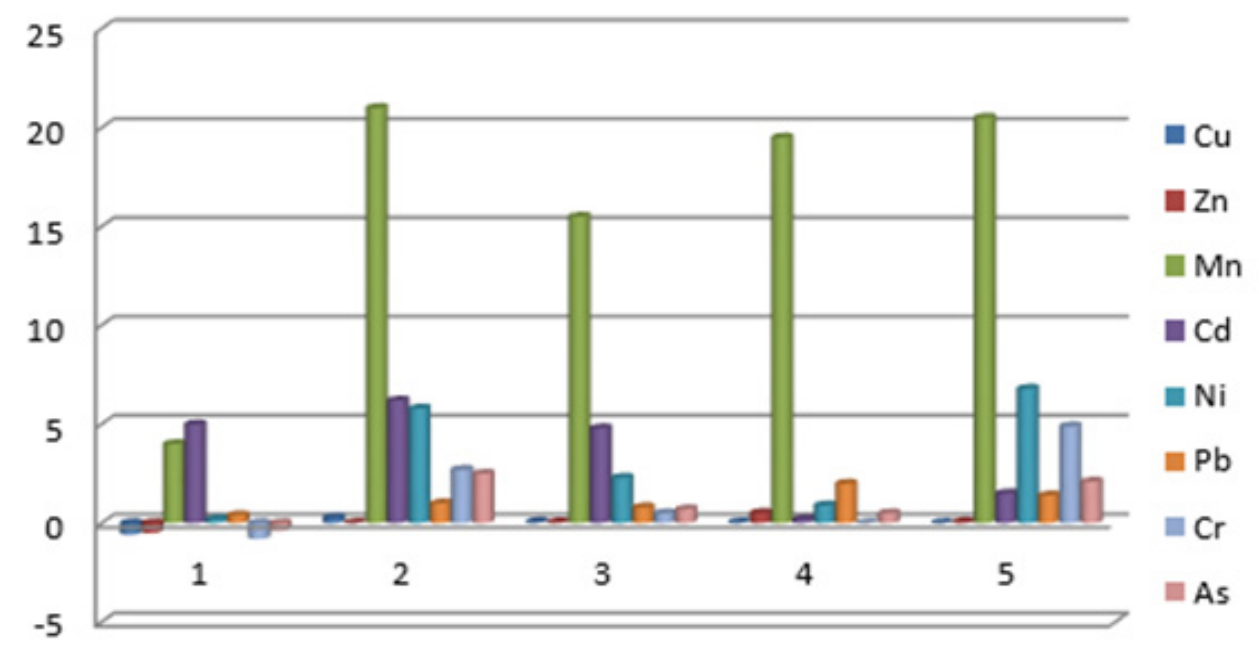

Figure 7: Heavy metal Pollution indecies of the study sites.

\section{Pollution and Index Models}

Table 1 shows various index ranges for pollution index, pollution load index, geo-accumulation index and potential ecological risk index. The table describes categories of soil contamination status with corresponding index values which was used as reference point to infer the contamination level of the soil in the present study.

Table 1: Showing the Index Standards.

\begin{tabular}{|c|c|c|c|c|c|c|c|c|c|}
\hline PI & Category & PLI & Category & GAI & Category & E_I & Category & PERI & Category \\
\hline $\mathrm{PI}<1$ & low contamination factor & $\mathrm{PLI}<1$ & $\begin{array}{c}\text { Soil } \\
\text { Perfection }\end{array}$ & $\mathrm{GAI}<0$ & $\begin{array}{c}\text { Practically } \\
\text { uncontaminated }\end{array}$ & $<40$ & Slight & $<90$ & Slight \\
\hline $1<\mathrm{PI}<3$ & $\begin{array}{l}\text { Moderate contamination } \\
\text { factor }\end{array}$ & PLI=1 & $\begin{array}{l}\text { Baseline level } \\
\text { of pollutants }\end{array}$ & $0<\mathrm{GAI}<1$ & $\begin{array}{c}\text { Moderately } \\
\text { uncontaminated }\end{array}$ & $40-80$ & Moderate & $90-180$ & Moderate \\
\hline $3<\mathrm{PI}<6$ & $\begin{array}{l}\text { Considerable contamination } \\
\text { factor }\end{array}$ & PLI>1 & $\begin{array}{l}\text { Deterioration } \\
\text { of site }\end{array}$ & $1<\mathrm{GAI}<2$ & $\begin{array}{c}\text { Moderately } \\
\text { contaminated }\end{array}$ & $80-160$ & Strong & $\begin{array}{l}180- \\
360\end{array}$ & Strong \\
\hline \multirow[t]{2}{*}{$6>\mathrm{PI}$} & $\begin{array}{l}\text { Very high contamination } \\
\text { factor }\end{array}$ & & & $2<\mathrm{GAI}<3$ & $\begin{array}{c}\text { Heavily } \\
\text { contaminated }\end{array}$ & $160-320$ & $\begin{array}{l}\text { Very } \\
\text { strong }\end{array}$ & $\begin{array}{l}380- \\
720\end{array}$ & Very strong \\
\hline & & & & $5<\mathrm{GAI}<6$ & $\begin{array}{l}\text { Extremely } \\
\text { contaminated }\end{array}$ & $>320$ & $\begin{array}{l}\text { Highly } \\
\text { strong }\end{array}$ & $>720$ & $\begin{array}{l}\text { Highly } \\
\text { strong }\end{array}$ \\
\hline
\end{tabular}


Figure 7 shows the pollution index (PI) pattern of the heavy metals in various study sites. Soils from the control site i.e SS1 had PI ranging between -0.8- 0.4 for $\mathrm{Cr}, \mathrm{Cu}, \mathrm{Zn}, \mathrm{As}, \mathrm{Ni}$ and $\mathrm{Pb}$. Also, the soil has PI values of 4 and 5 respectively for Mn and Cd. Given the observation, Table 1 categorized the soil as being contaminated with $\mathrm{Cr}, \mathrm{Cu}, \mathrm{Zn}, \mathrm{As}, \mathrm{Ni}$ and $\mathrm{Pb}$ at low level and moderately contaminated with $\mathrm{Mn}$ and $\mathrm{Cd}$. With the average PI value range of $0.02-1$, soils of SS2 were contaminated at low level with $\mathrm{Zn}, \mathrm{Cu}$ and $\mathrm{Pb}$ but the soils had moderate contaminations of $\mathrm{Cr}$ and As having average PI values of 2.7 and 2.5 respectively. Also, soils from SS2 were considerably contaminated by $\mathrm{Ni}$ and Cd with mean PI values of 5.2 and 6.2 respectively and highly contaminated with Mn having the highest mean PI value of 21 as shown on Table 1. Like in SS2, contaminations of $\mathrm{Zn}$ and $\mathrm{Cu}$ were very low in the soils from SS3, SS4 and SS5 hence PI range value of 0.01-0.068. Contamination of Mn was also very high in the soils SS3, SS4 and SS5 with PI values of 15.5, 19.5 and 21.5 respectively. Soils of SS3, SS4 and SS5 were contaminated with $\mathrm{Cd}$ and $\mathrm{Ni}$ at between low and high levels with PI range values of 0.2- 6.8 whereas $\mathrm{Pb}, \mathrm{Cr}$ and As contaminated the soils at between low and moderate levels.

Figure 8 represents the degree of contamination of various study sites by the metals. All the sites including the control site (SS1), recorded pronounced value for $\mathrm{Mn}$, however $\mathrm{Mn}$ had the highest degree of contamination in SS2, the effluent receiving site, with marginal difference in SS1. Also, the degree of $\mathrm{Cd}$ contamination was prominent in SS1 indicating that $\mathrm{Mn}$ and Cd predominantly originated from natural sources. Apparently, the varying degrees of contamination values for $\mathrm{As}, \mathrm{Ni}, \mathrm{Cu}, \mathrm{Zn}, \mathrm{Cr}$ and $\mathrm{Pb}$ observed in the other sites, could be traced to anthropogenic sources. On the average, the degree of contamination of the sites by the heavy metals was highest for $\mathrm{Mn}$ and lowest for $\mathrm{Cu}$. nevertheless, the degree of heavy metal contamination in the soils of the study sites decreased in this order- $\mathrm{Mn}>\mathrm{Cd}>\mathrm{Ni}>\mathrm{Cr}>\mathrm{Pb}>\mathrm{As}>\mathrm{Zn}>\mathrm{Cu}$. Pollution load indices of the heavy metals in all the sites are presented in Figure 9. The lowest PLI value (0.5) of the heavy metals observed in SS1 suggested soil perfection $(\mathrm{PLI}<1)$ in the site. The perceived low PLI value is indicative of low influence of anthropogenic activity in the study site. The other study sites (SS2, SS3, SS4 and SS5) had high heavy metal PLI values of 3.62, 2.842 .00 and 2.82 respectively. The prevailing PLI values is an evidence of high heavy metal impact on the soils which depicts soil deterioration (PLI $>1$ ) as shown on the Table 1 . The average pollution load index value of all the sites was also determined and the value is at 2.63 , placing the average soil quality at the category of soil deterioration as presented on the table Data analysis to determine goe-accumulation and ecological potential risk of the investigated metals was carried out. From the goe accumulation analysis which was compared with the index standard shown on Table 1, the study area was practically uncontaminated with $\mathrm{Zn}$ and $\mathrm{Pb}$, moderately uncontaminated with $\mathrm{Cu}, \mathrm{Ni}, \mathrm{Cr}$ and $\mathrm{As}$, moderately contaminated with $\mathrm{Mn}$ and heavily contaminated with Cd. Goe-accumulation of metal in soils is apparently a function of soil property and affinity of the metals to the soil [25] and also dependent on the level of pollution of groundwater [26]. The implication of low accumulation index of the metals is that the less amount of the metal is sorbed or diffused into the soil matrix perhaps due to lack of strong affinity to the soil. The prevailing condition allows heavy metals advection through the pore water to the aquifer, which portends danger to ground water. Conversely, high metal Goe-accumulation encourages low advection with the soil bulk water flow, thus posing less danger to groundwater $[27,28]$ In view of the present scenario, $\mathrm{Zn}, \mathrm{Pb}$, $\mathrm{Cu}, \mathrm{Ni}, \mathrm{Cr}$ and As are likely threats to portability of groundwater. The single potential ecological risk index analysis for individual metals shows that the study site is at strong risk of $\mathrm{Cd}$ and $\mathrm{Mn}$ pollution whereas the study site is at within the range of slight and moderate ecological risk of pollution of the metals. On the average, the potential ecological risk of study site by the metals is strong.

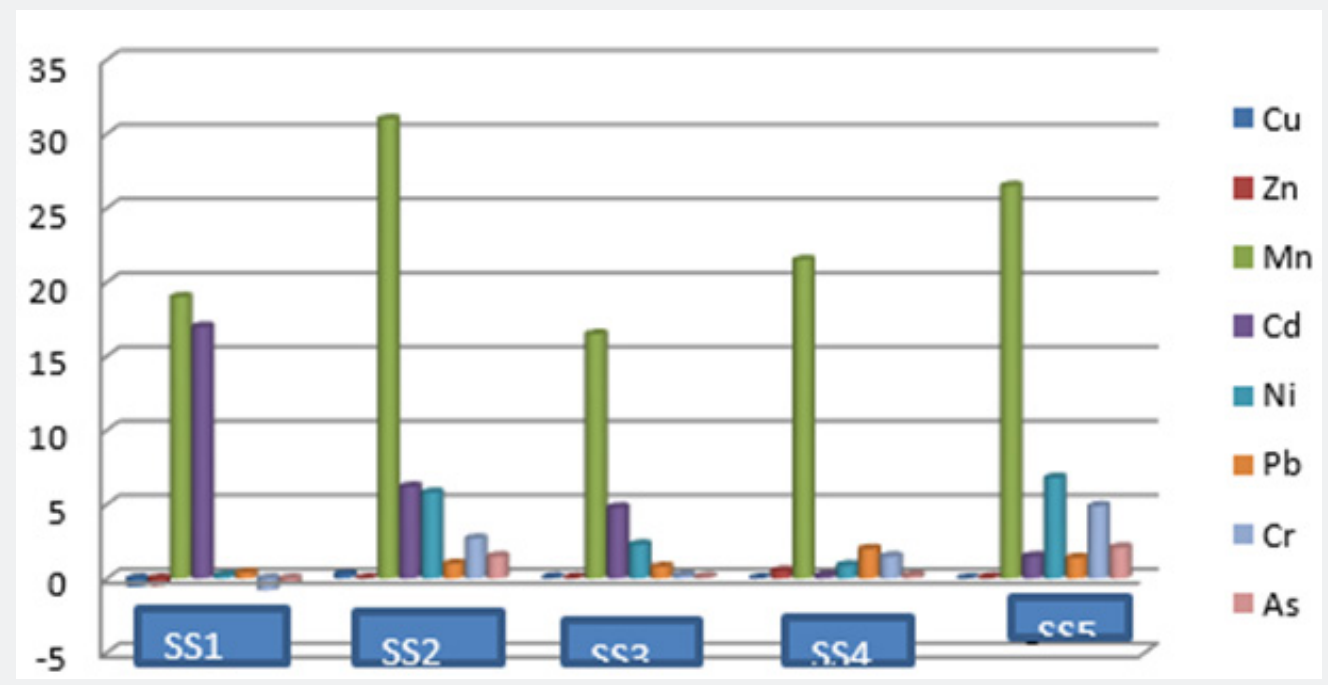

Figure 8: Degree of contamination by heavy metals in various sites. 


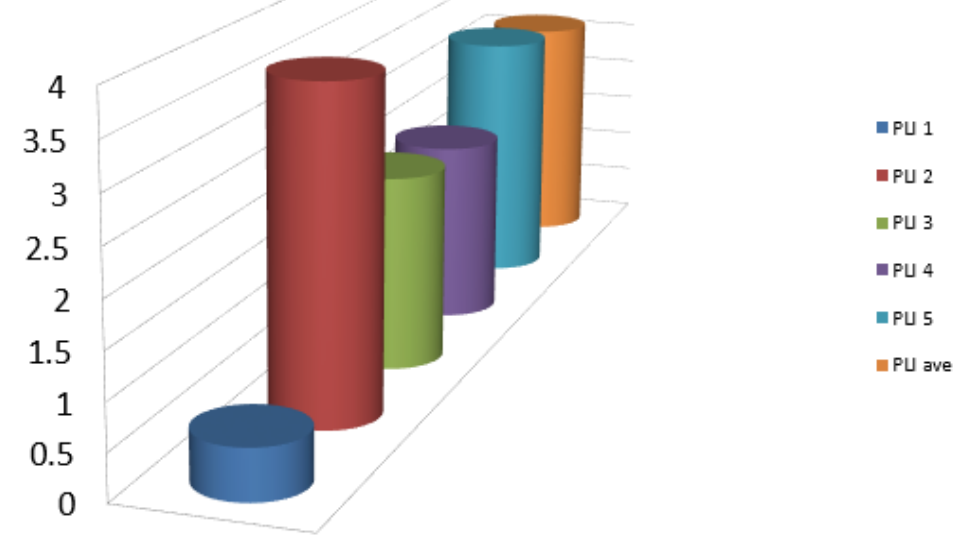

1

Figure 9: Pollution load index in various sampling sites and average pollution index of the sites.

\section{Statistical Analysis}

A correlational analysis was performed to know if the metals are associated with one another. Specifically, a bivariate correlational analysis is carried out using Pearson's correlation coefficient formular to determine the level of association between any two of the metals. The results of the analysis is shown in Table 2 below.

Table 2: Results of Bivariate Correlations between the Metals.

\begin{tabular}{|c|c|c|c|c|c|c|c|c|c|}
\hline & & $\mathrm{Cu}$ & Zn & Mn & Cd & $\mathbf{P b}$ & $\mathrm{Ni}$ & $\mathrm{Cr}$ & As \\
\hline \multirow[t]{3}{*}{$\mathrm{Cu}$} & Pearson Correlation & 1 & -.461 & -.078 & -.626 & $.880^{*}$ & -.197 & -.180 & -.293 \\
\hline & Sig. (2-tailed) & & .435 & .900 & .259 & .049 & .751 & .772 & .633 \\
\hline & $\mathrm{N}$ & 5 & 5 & 5 & 5 & 5 & 5 & 5 & 5 \\
\hline \multirow[t]{3}{*}{$\mathrm{Zn}$} & Pearson Correlation & -.461 & 1 & .540 & -.387 & -.024 & .874 & $.953^{*}$ & $.920^{*}$ \\
\hline & Sig. (2-tailed) & .435 & & .348 & .519 & .969 & .052 & .012 & .027 \\
\hline & $\mathrm{N}$ & 5 & 5 & 5 & 5 & 5 & 5 & 5 & 5 \\
\hline \multirow[t]{3}{*}{$\mathrm{Mn}$} & Pearson Correlation & -.078 & .540 & 1 & -.248 & .245 & .769 & .620 & .802 \\
\hline & Sig. (2-tailed) & .900 & .348 & & .688 & .691 & .128 & .265 & .102 \\
\hline & $\mathrm{N}$ & 5 & 5 & 5 & 5 & 5 & 5 & 5 & 5 \\
\hline \multirow[t]{3}{*}{$\mathrm{Cd}$} & Pearson Correlation & -.626 & -.387 & -.248 & 1 & -.871 & -.509 & -.622 & -.439 \\
\hline & Sig. (2-tailed) & .259 & .519 & .688 & & .055 & .381 & .263 & .459 \\
\hline & $\mathrm{N}$ & 5 & 5 & 5 & 5 & 5 & 5 & 5 & 5 \\
\hline \multirow[t]{3}{*}{$\mathrm{Pb}$} & Pearson Correlation & $.880^{*}$ & -.024 & .245 & -.871 & 1 & .287 & .257 & .175 \\
\hline & Sig. (2-tailed) & .049 & .969 & .691 & .055 & & .640 & .676 & .778 \\
\hline & $\mathrm{N}$ & 5 & 5 & 5 & 5 & 5 & 5 & 5 & 5 \\
\hline \multirow[t]{3}{*}{$\mathrm{Ni}$} & Pearson Correlation & -.197 & .874 & .769 & -.509 & .287 & 1 & $.903^{*}$ & $.982 * *$ \\
\hline & Sig. (2-tailed) & .751 & .052 & .128 & .381 & .640 & & .036 & .003 \\
\hline & $\mathrm{N}$ & 5 & 5 & 5 & 5 & 5 & 5 & 5 & 5 \\
\hline \multirow[t]{3}{*}{$\mathrm{Cr}$} & Pearson Correlation & -.180 & $.953^{*}$ & .620 & -.622 & .257 & $.903^{*}$ & 1 & $.933^{*}$ \\
\hline & Sig. (2-tailed) & .772 & .012 & .265 & .263 & .676 & .036 & & .021 \\
\hline & $\mathrm{N}$ & 5 & 5 & 5 & 5 & 5 & 5 & 5 & 5 \\
\hline \multirow[t]{3}{*}{ As } & Pearson Correlation & -.293 & $.920 *$ & .802 & -.439 & .175 & $.982^{* *}$ & $.933^{*}$ & 1 \\
\hline & Sig. (2-tailed) & .633 & .027 & .102 & .459 & .778 & .003 & .021 & \\
\hline & $\mathrm{N}$ & 5 & 5 & 5 & 5 & 5 & 5 & 5 & 5 \\
\hline
\end{tabular}

*. Correlation is significant at the 0.05 level (2-tailed).

**. Correlation is significant at the 0.01 level (2-tailed). 
The results in Table 2 show that there is significant correlation coefficient between $\mathrm{Cu}$ and $\mathrm{Pb}$ at $5 \%$ significant level since the probability value (P-value) of $0.049(\mathrm{P}<0.05)$ was obtained. This correlation coefficient was found to be positively high. This implies that as the quantity of $\mathrm{Cu}$ increases, the quantity of $\mathrm{Pb}$ also increases. This further implies that $\mathrm{Cu}$ has strong positive association with $\mathrm{Pb}$. It was found out that associations between $\mathrm{Cu}$ and the other metals under study were insignificant since the correlation coefficient between $\mathrm{Cu}$ and each of them was not significant at $5 \%$ level of significance $(\mathrm{P}<0.05)$. The results also show that $\mathrm{Zn}$ is significantly and positively correlated with $\mathrm{Cr}$ and as each at $5 \%$ level of significance since $\mathrm{P}=0.012<0.05$ and $\mathrm{P}=0.027<0.05$. Thus, as the quantity of $\mathrm{Zn}$ increases, so do the quantities of $\mathrm{Cr}$ and $\mathrm{As}$. In the same vein, $\mathrm{Zn}$ had strong positive associations with $\mathrm{Cr}$ and As. Similarly, Ni was significantly correlated with $\mathrm{Cr}$ and As at 5\% and 10\% levels of significance respectively with the respective P-values 0.036 and 0.003 . Therefore, as the quantity of $\mathrm{Cr}$ increases, so does the quantity of As. Given that some of the metals are significantly correlated, the presence of a given metal can be used to account for the presence of another metal that is correlated with it. Therefore, a principal component analysis was carried out to identify the two most important metals that can account for variation in the other metals. The results of the principal component analysis are shown in Table 3 below.

Table 3: Principal Component Analysis Results showing Total Variation.

\begin{tabular}{|c|c|c|c|}
\hline Components & \multicolumn{3}{|c|}{ Initial Eigenvalues } \\
\hline & Total & $\begin{array}{c}\text { Percentage of } \\
\text { Variance }\end{array}$ & $\begin{array}{c}\text { Cumulative } \\
\text { Percentage }\end{array}$ \\
\hline 1 & 4.742 & 59.278 & 59.278 \\
\hline 2 & 2.538 & 31.726 & 91.004 \\
\hline 3 & 0.631 & 7.886 & 98.80 \\
\hline 4 & 0.089 & 1.110 & 100.00 \\
\hline 5 & $5.697 \mathrm{E}-0.16$ & $7.122 \mathrm{E}-0.15$ & 100.00 \\
\hline 6 & $9.492 \mathrm{E}-0.17$ & $1.186 \mathrm{E}-0.15$ & 100.00 \\
\hline 7 & $-1.377 \mathrm{E}-0.16$ & $-1.721 \mathrm{E}-0.15$ & 100.00 \\
\hline 8 & $-1.502 \mathrm{E}-0.16$ & $-1.877 \mathrm{E}-0.15$ & 100.00 \\
\hline
\end{tabular}

The results of the principal component analysis show that the total variations can be explained by the first two components, $59.278 \%$ and $31.726 \%$ respectively. This implies that only these two components are significant in explaining the variations. Therefore, contributions of the other components are not important. The results show that these two components explained $91.004 \%$ of the total variation. The two components are identified in Table 4 below. Table 4 shows that As and $\mathrm{Cu}$ can explain about $91 \%$ of the variations of the metals in the discharge points since as explained the highest variation in the first component (0.979) and $\mathrm{Cu}$ explained the highest variation in the second component (0.987). Therefore, the two significant metals in the discharge points are As and $\mathrm{Cu}$. This further implies that as contains some of the metals found in the sites especially the metals in the first component while $\mathrm{Cu}$ contains the rest of the metals (especially the ones in the second component). This further implies that the presence of as in a site could be used to explain the presence of $\mathrm{Ni}, \mathrm{Cr}, \mathrm{Zn}, \mathrm{Mn}, \mathrm{Pb}$ and $\mathrm{Cd}$ in that site. On the other hand, the presence of $\mathrm{Cu}$ in a site could be used to explain the presence of $\mathrm{Pb}$ in that site. In order to find out if there is significant difference in the mean deposits of the metals among the sites (discharge points) which will go a long way to determining the site that is most highly potential at risk, analysis of variance and post-hoc analyses were carried out. The results are shown in Tables 5 \& 6 respectively. The results in Table 5 show that there is no significant difference in the mean deposits of the metals at the discharge points. Following this, a Post-Hoc analysis was carried out to find out if there exist significant difference in the mean deposits of the metals between any pair of discharge points. This was done with the aid of the LeastSquare Significant Difference. The results are shown in Table 6 below. The results show that significant differences exist only in the mean deposits between the Control Site (SS1) and the main Discharge point (SS2) on one hand and between the Control Site (SS1) and the Spill point (SS5) on the other hand. These results imply that deposition of refuse at any site contributes to the quantity of metals formed in that site. This further implies that underground water at the main Discharge point and Spill point face more risk of being contaminated by the metals.

Table 4: Component Matrix.

\begin{tabular}{|c|c|c|}
\hline Elements & \multicolumn{2}{|c|}{ Components } \\
\hline & 1 & 2 \\
\hline $\mathrm{As}$ & 0.979 & \\
\hline $\mathrm{Ni}$ & 0.973 & \\
\hline $\mathrm{Cr}$ & 0.966 & -0.335 \\
\hline $\mathrm{Zn}$ & 0.900 & \\
\hline $\mathrm{Mn}$ & 0.765 & 0.987 \\
\hline $\mathrm{Cu}$ & & 0.931 \\
\hline $\mathrm{Pb}$ & 0.346 & -0.734 \\
\hline $\mathrm{Cd}$ & 0.613 & \\
\hline
\end{tabular}

Table 5: Analysis of Variance (ANOVA) Results.

\begin{tabular}{|c|c|c|c|c|c|}
\hline $\begin{array}{c}\text { Sum of } \\
\text { Squares }\end{array}$ & df & $\begin{array}{c}\text { Mean } \\
\text { Square }\end{array}$ & F & Sig. & \\
\hline $\begin{array}{c}\text { Between } \\
\text { Groups }\end{array}$ & 52.062 & 4 & 13.016 & 2.223 & .087 \\
\hline $\begin{array}{c}\text { Within } \\
\text { Groups }\end{array}$ & 204.958 & 35 & 5.856 & & \\
\hline Total & 257.020 & 39 & & & \\
\hline
\end{tabular}




\section{International Journal of Environmental Sciences \& Natural Resources}

Table 6: Results of Multiple Comparison Test in the Mean Deposits of the Metals between Pair of Sites (Post-Hoc Analysis).

\begin{tabular}{|c|c|c|c|c|c|c|}
\hline \multirow{2}{*}{ (I) Sites } & \multirow{2}{*}{ (J) Sites } & \multirow{2}{*}{$\begin{array}{c}\text { Mean Difference } \\
(I-J)\end{array}$} & \multirow{2}{*}{ Std. Error } & \multirow{2}{*}{ Sig. } & \multicolumn{2}{|c|}{ 95\% Confidence Interval } \\
\hline & & & & & Lower Bound & Upper Bound \\
\hline \multirow{4}{*}{1} & 2 & $-2.804375^{*}$ & 1.209951 & .026 & -5.26071 & -.34804 \\
\hline & 3 & -1.333500 & 1.209951 & .278 & -3.78983 & 1.12283 \\
\hline & 4 & -.890375 & 1.209951 & .467 & -3.34671 & 1.56596 \\
\hline & 5 & $-2.986625^{*}$ & 1.209951 & .019 & -5.44296 & -.53029 \\
\hline \multirow{4}{*}{2} & 1 & $2.804375^{*}$ & 1.209951 & .026 & .34804 & 5.26071 \\
\hline & 3 & 1.470875 & 1.209951 & .232 & -.98546 & 3.92721 \\
\hline & 4 & 1.914000 & 1.209951 & .123 & -.54233 & 4.37033 \\
\hline & 5 & -.182250 & 1.209951 & .881 & -2.63858 & 2.27408 \\
\hline \multirow{4}{*}{3} & 1 & 1.333500 & 1.209951 & .278 & -1.12283 & 3.78983 \\
\hline & 2 & -1.470875 & 1.209951 & .232 & -3.92721 & .98546 \\
\hline & 4 & .443125 & 1.209951 & .716 & -2.01321 & 2.89946 \\
\hline & 5 & -1.653125 & 1.209951 & .181 & -4.10946 & .80321 \\
\hline \multirow{4}{*}{4} & 1 & .890375 & 1.209951 & .467 & -1.56596 & 3.34671 \\
\hline & 2 & -1.914000 & 1.209951 & .123 & -4.37033 & .54233 \\
\hline & 3 & -.443125 & 1.209951 & .716 & -2.89946 & 2.01321 \\
\hline & 5 & -2.096250 & 1.209951 & .092 & -4.55258 & .36008 \\
\hline \multirow{4}{*}{5} & 1 & $2.986625^{*}$ & 1.209951 & .019 & .53029 & 5.44296 \\
\hline & 2 & .182250 & 1.209951 & .881 & -2.27408 & 2.63858 \\
\hline & 3 & 1.653125 & 1.209951 & .181 & -.80321 & 4.10946 \\
\hline & 4 & 2.096250 & 1.209951 & .092 & -.36008 & 4.55258 \\
\hline
\end{tabular}

\section{Conclusion}

Applications of pollution indexs and statistical models on the Assessment and distributions of the heavy metals on the typical Paint Manufacturing Waste Contaminated soil of Niger Delta Nigeria has been studied. Concentration values of the metals virtually exceeded the limits prescribed by the WHO standards. Comparing the heavy metal concentration values in the various sampling sites of the study area with the control site, high values were apparent on the study sites. Elevation of the sites affected the distribution of heavy metals in, as the sites in the low elevation experienced high concentration values despite the proximity of the waste source. Given the pollution index, geo-accumulation and ecological model analysis, the sites were reasonably contaminated with $\mathrm{Mn}$ and $\mathrm{Cd}$. Strong correlation existed between $\mathrm{Cu}$ and $\mathrm{Pb}, \mathrm{Zn}$ with $\mathrm{As}$ and $\mathrm{Cr}$, Ni with $\mathrm{Cr}$ and $\mathrm{As}$. There was no significant difference in the mean concentration values of the metals at the discharge points, however, significant difference was glaring in the metal discharge between (SS1), and SS2, SS3 SS4 and SS5 respectively. This study therefore provides insight to policy makers and other stakeholders on the extent of soil pollution by the paintoriented waste in a typical Niger delta soil. It is also important to know that heavy metals which significantly contaminated the soil accumulate on the soil matrix, perhaps translocate to plant tissues, and may not pose much threat to ground water, but by contaminant migration principles, the other metals which are not much in the soil might have by advection, move with the bulk soil water flow to aquifer.
The subsequent research studies can leverage on this hypothesis to ascertain this postulation on the study site.

\section{Acknowledgment}

We sincerely thank the staff and management of the institute of erosion, federal university of technology owerri for the soil analysis. The painstaking analysis of the technical staff in the chemistry laboratory of the school to determine the values of the heavy metals was highly appreciated.

\section{References}

1. Yuanan Hu, Xueping Liu, Jinmei Bai, Kaimin Shih, Eddy Y Zeng, et al. (2013) Assessing heavy metal pollution in the surface soils of a region that had undergone three decades of intense industrialization and urbanization. Environmental Science pollution res 23(4): 131-141.

2. Morgan R (2013) Soil Heavy Metals, and Human Health. In Brevik EC, Burgess LC (Eds.); Soils and Human Health. Boca Raton FL: CRC Press, USA pp. 59-80.

3. European Commission (2012) The State of Soil in Europe - A contribution of the JRC to the European Environment Agency's State and Outlook Report - SOER 2010. Luxembourg: Publications Office of the European Union.

4. Cheng H, Hu Y (2012) Mercury in municipal solid waste in China and its control: A review. Environ Sci Technol 46(2): 593-605.

5. Yaylali Abanuz G (2011) Heavy metal contamination of surface soil around Gebze industrial area, Turkey. Microchem J 99(1): 82-92.

6. Li X, Wai OWH, Li YS, Coles BJ, Ramsey MH, et al. (2000) Heavy metal distribution in sediment profiles of the Pearl River estuary, South China. Appl Geochem 15(5): 567-581. 
7. Li X, Shen Z, Wai OWH, Li YS (2001) Chemical forms of Pb, Zn and Cu in the sediment profiles of the Pearl River Estuary. Mar Pollut Bull 42(3): 215-223.

8. Nagajyoti PC, Lee KD, Sreekanth TVM (2010) Heavy metals, occurrence and toxicity for plants: A review. Environ Chem Lett 8(3): 199-216.

9. Zhang X, Lin F, Jiang Y, Wang K, Wong MTF (2008) Assessing soil Cu content and anthropogenic influences using decision tree analysis. Environ Pollut 156(3): 1260-1267.

10. Bassey FI, Iwegbue CMA, Obi Iyeke GE, Tesi GO, Rotu AR (2014) Heavy metals in soils and tomatoes grown in urban fringe environment in Asaba, Delta State, Nigeria. Nigerian Journal of Basic and Applied Science 22(1\&2): 27-31.

11. Hani A, Kariminejad M (2010) Toxic metal distribution in soils of Kaveh Industrial city, Iran. World Applied Sciences Journal 8(11): 1333 -1342 .

12. Hakanson L (1980) An ecological risk index for aquatic pollution control. A Sedimentological approach, Water Rsearch 14: 975- 1001.

13. Lugwisha Esther Hellen, Othman Chande Othman (2016) Heavy Metal Levels in Soil, Tomatoes and Selected Vegetables from Morogoro Region, Tanzania. International Journal of Environmental Monitoring and Analysis 4(3): 82-88.

14. European commission (2013) Science for Environment Policy INDEPTH REPORT Soil Contamination: Impacts on Human Health.

15. Tina Porwal MLB, Girls PG. College, Indore (MP) Paint pollution harmful effects on environment. Social Issues and Environmental Problems 3(9): 1-4.

16. Colak H, Soylak M, Turkoglu O (2005) Determination of trace metal content of various herbal and fruit teas produced and marketed from Turkey. Trace Elem Electrolytes 22: 192-195.

17. Lue XL, Wang K, Lei JH, Zhai Y (2008) Contamination assessment of copper, lead, zinc, manganese and nickel in street dust of Baoji, NW China. J Hazard Mater 4: 52.

18. Thabet A Mohamed, Mohamed Abuel-Kassem Mohamed, Ragab Rabeiy, Mahmoud A Ghandour (2014) Application of pollution indices for evaluation of heavy metals in soil close to phosphate fertilizer plant, Assiut, Egypt. Assiut University Bulletin for Environmental Researches. 17 (1)

19. Oladele E O, PGC Odeigah T Yahaya (2011) Toxic Effects of Three Industrial Effluents on Growth and Development of Vigna unguiculata (L) Walp (Cultivar it 84 E-124). Journal of Biological Sciences 11: 320-325.

20. Handbook of Federal Ministry of Environment of Nigeria 2002.

21. Noor ul A, Tauseef A (2015) Contamination of soil with heavy metals from industrial effluent and their translocation in green vegetables of Peshawar. Pakistan RSC Advances 5: 14322-14329.

22. Malik RN, Husain SZ, Nazir I (2010) Heavy metal contamination and accumulation in soil and wild plant species from industrial area of Islamabad. Pakistan J of Bot 42(1): 291-301.

23. Xu Z, Ni S, Tuo X, Zhang C (2008) Calculation of heavy metals' toxicity coefficient in the evaluation of potential ecological risk index. Huangjin Kexue yu Jishu 31(2): 112-115.

24. Cloquet C, Carignan J, Libourel G, Sterckeman T, Perdrix E (2006) Tracing source pollution in soils using cadmium and lead isotopes. Environ Sci Technol 40(8): 2525-2530.

25. Chen TB, Zheng YM, Lei M, Huang CH, Wu H, et al. (2005) Assessment of heavy metal pollution in surface soils of urban parks in Beijing, China. Chemosphere 60: 542- 551.

26. Mohamed AAJ, Ibrahim AR, Lee HL, Khamis SA, Mwevura H, et al. (2016a) An Index Approach to Metallic Pollution in Groundwater Sources of South Region of Pemba Island. Scie J Analyt Chem 4: 12-21.

27. Mohamed AAJ, Ibrahim AR, Lee HL, Hanna M, Mohamed M, et al. (2016b) Assessment of Groundwater Quality Parameters in Northern Region of Zanzibar Island. J Chem Eng Bioanalyticalchem 1: 1-8.

28. Abdul Ali Juma Mohamed, Sara Abdalla Khamis, Haji Mwevura, Miza Al Kombo, Said Suleiman Bakari (2016) Risk Assessment on Trace Metals in Groundwater and Springs in Urban Environment of Zanzibar Island. International Journal of Environmental Monitoring and Analysis 4(2): 45-55.

\section{Your next submission with Juniper Publishers} will reach you the below assets

- Quality Editorial service

- Swift Peer Review

- Reprints availability

- E-prints Service

- Manuscript Podcast for convenient understanding

- Global attainment for your research

- Manuscript accessibility in different formats

( Pdf, E-pub, Full Text, Audio)

- Unceasing customer service

Track the below URL for one-step submission

https://juniperpublishers.com/online-submission.php 